\title{
Public Private Partnership in Agriculture: A Stern Review
}

\author{
Chandan Kumar Rai ${ }^{1}$, Arti $^{2}$, Sanjeev Kumar ${ }^{1}$, Abul K. Azad ${ }^{1}$ and Mukesh Kumar ${ }^{1}$ \\ ${ }^{1}$ Division of Dairy Extension, ICAR-NDRI, Karnal-132001, Haryana, India \\ ${ }^{2}$ DES \& M, ICAR-NDRI, Karnal-132001, Haryana, India \\ *Corresponding author
}

\section{Keywords \\ Agriculture, Public private partnership, Farming community, Private sector, Revenue sharing model and Extension. \\ Article Info \\ Accepted: \\ 10 July 2017 \\ Available Online: \\ 10 September 2017}

\section{A B S T R A C T}

The critical review of various study revealed that Public Private Partnerships offer potentially important opportunities for growth and development of developing countries (Spielman and Grebmer, 2004).Low public sector funding for agricultural sector and lack of incentives for the private sector to operate in areas where there is no market largely explain the yield gap in many food-importing developing countries. Yet, there are effective ways in which the public and the private sector could work together and jointly improve agricultural sustainability in poor countries i.e. PPP. It is risk sharing, cooperative, collaborative, contractual relationships with flexible ownership between two or more public and private sectors, typically of a long-term nature contributing for one or more functions like planning, resources and activities as required to accomplish a shared goal set out by the partners. It provides opportunities for information management, technological management, community mobilization, economic empowerment of farmers and women, reducing risk and uncertainty and fastens the implementation, reduces life cycle cost and optimizes risk of agricultural project. It allows the public sector to derive benefits from the efficiency and effectiveness of the private sector. It also have some limitations as agriculture suffers due to problems linked with supply of raw materials, mode of procurement and rate fixing and thereby affecting cooperation and coordination between the partners. This paper presented a stern review of all the aspect of Public Private Partnership in agriculture, its concept and meaning, different models, dimensions, impact and limitations.

\section{Introduction}

Agriculture is the main source of livelihood in developing countries. Two third populations of developing countries are dependent on agriculture for their bread directly or indirectly. For improving the condition of these people there is a need to develop the agriculture of these regions. Now a days Public Private Partnerships (PPP) in agricultural provide opportunities for conducting advanced research, developing new technologies, and deploying new products for the benefit of small-scale, resource-poor farmers and other marginalized social groups in developing countries (Anonymous, 2014). A public private partnership is a cooperative and collaborative arrangement between two or more public and private sectors, typically of a long-term nature (Hodge and Greve, 2007). The latest buzz word in the present situation is Public Private Partnership (PPP). This PPP has revolutionized the public sector for effective 
delivery of the goods. Complete privatization may act as a barrier to free flow of public goods. This encourages adopting PPP model.

\section{Public private partnership: meaning and concept}

In India PPP is defined as "a partnership between a public sector entity and a private sector entity $(51 \%$ or more of equity is with the private partner/s) for the creation and/or management of infrastructure for public purpose for a specified period of time (concession period) on commercial terms and in which the private partner has been procured through a transparent and open procurement system" (Nanda, S.S., 2015).The term public private partnership in the present context is necessarily a collaborative effort between the public and private sectors contributing for one or more functions like planning, resources and activities as required to accomplish a shared goal set out by the partners. It is risk sharing, cooperative and contractual relationships with flexible ownership between public and private sectors. The PPP approach supplements scarce public resources, creates a more competitive environment and helps to improve efficiencies and reduce costs. The rationale for public sector involvement differs between different kinds of services and influences the type of involvement required (Paul and Margaret 2003). Risk allocation plays a vital role in PPP management. Preplanned proposals with time frame, budget, methods and materials would result in expected outcome of PPP, for which it is established.

\section{Need for PPP}

Public Private Partnership is most preferred in developing countries for effective delivery of infrastructure facilities like transportation, education and health care services as it is more successful there. In developing countries, rural-urban migration has increased urbanization at same time socio-economic developments have increased the demand for infrastructure and also pressure on maintaining and operating the existing infrastructure. Thus private sector could be attracted through mutually beneficial agreement for efficient use of resources, availability of modern technology, better project design and implementation and improved operation combine to deliver efficiency. Public Private Partnership also fastens the implementation, reduces life cycle cost and optimizes risk. The important feature of Public Private Partnership is its ability to seek finance from private sector, when the funding is limited from public sector.

\section{Relevance of PPP in agriculture}

Agriculture, being backbone and support system of rural economy should be strengthened, if we want paradigm shift in the approach and its development. With the advent many popular and appropriate technology, many innovations are also brought in the field of agriculture. This is now an ominous task before the policy makers and government to feed the ever increasing population while preserving and conserving the resources as well. Hence, PPP has an immense role to play in agriculture sector.PPP offers a win-win solution for all stakeholders. PPP allows the government to tap the private sector's capacity to innovate. It can be implemented in a number of areas like agricultural research, agricultural supply chain management, watershed management, agricultural extension management, Biotechnology, etc. PPP in Agricultural Research: Till date, PPP is more in the research field when compare to other fields of agricultural sector. The private sector has invested a lot for undertaking the research, as developing countries in particular, are not in the position to do so. Research through PPP is 
carried out for enhancing agricultural productivity both in quality and quantity, developing ways for the use of depleted resources, lowering the food prices, and accumulating the capital resources among the vulnerable sections.

\section{PPP in irrigation}

Proper irrigation and water availability at the right time is the major problem for agriculture since a long time. This creates a vicious circle of problems for the countries that are totally dependent on monsoon. Inconsistency and erratic nature of weather along with natural disasters enhance the woes for the poor farmers. To address the problems, PPP in the area of large scale irrigation and drainage schemes through participation is seen in water supply and sanitation. The success of PPP in water supply and sanitation has given some lessons which can be utilized for irrigation and drainage purpose.

\section{PPP in agricultural extension management}

Agricultural extension has a significant role to play towards attainment of self-reliance. But in the context of multi-faceted problems of the farmers, public extension alone has failed to address the farmers' needs. In most of the times public extension is under tremendous pressure due to limited resources, disparity ratio between farmers and extension personals, demand for quality, agreements and commitments under WTO, etc. A holistic approach which is needed can be provided by private farms, farming communities, SHGs, NGOs, media people, co-operatives, etc.

\section{Partnership for information sharing}

Public and private sector institutes both possess the knowledge needed to improve global agriculture. Collaborative projects are sharing practical agricultural information and cultivation of best practice among public and private sector organization and farmers.

\section{Revenue sharing model of PPP}

\section{Model 1}

This model is particularly suitable where the capital investment is low and many private vendors can be attracted to invest in to the venture. The revenues can be predicted with certainty; the fixed pay off variant will be useful.

\section{Model 2}

In this model the capital investment is done by the government and the business is run by the private partner. This model is especially useful where the government wishes to utilize the efficiency of private sector in running important citizen services. The financial risk in this model is taken by the government and also incurs the administrative risk. Government also becomes the major beneficiary of the revenue generated through this model.

\section{Model 3}

In this model both partners invest capital into project. Returns are shared as per the original capital investment ratio as well as the risk perception of the partners. Project requires large capital like oil refining etc, may fall under this category. This model tries to equally distribute the risk and return among Public Private Partnership partners. Government may make initial investment and then take annual revenue from their investments.

\section{Impacts of PPP in agriculture}

The good impact of PPP in any field depends on involvement of institutions and industries 
in seeking collaboration and combining all available public and private skills (Peter, 2002). PPP has made constructive modifications in social mobilization, economic empowerment, market linkage of farm produce, capacity building of farm families, decrease of risk and uncertainties, etc. (Hisrich and Peters, 2002).

\section{Information management}

Information management strategy in relation to PPP could result better production and delivery system to the farmers. From the review it was revealed that, this approach helped in replacement of traditional rice varieties with basmati rice, cultivation of medicinal and aromatic plants and mushroom in Patna district of Bihar. Farmers got an average net income of Rs. 22000/ha by diversifying from groundnut and paddy to maize in Chittoor district of Andhra Pradesh and also expanded maize area from 60 ha to 1150 ha (Srinath and Ponnusamy, 2011).

\section{Technological management}

Better technologies could be generated along with improving adeptness in management of PPP and improving the institutional intellectual property management skills and information database on available technologies in the public sector. Commercialization of $\mathrm{Bt}$ maize varieties based on partnership between Agricultural Genetic Engineering Institute (AGERI) of Egypt and Pioneer Hi-Bred Company, developing delayed ripening of Papaya between Syngenta and University of Nottingham, development of GM sweet potatoes in Kenya, development of super sorghum through nine globally respected institutions and completion of rice genome sequencing project in 2004 have resulted in high end technologies through PPP approach (Khush, 2005).

\section{Community mobilization}

Developmental departments carry out major efforts to activate the group dynamics among the community in order to create a better social linkage through SHG, Farmers' Clubs, Commodity groups, Farmers cooperative societies and Federations. These efforts would be more effective, when they are combined with the capable and reputed private partners. Programmes should be inclusive in nature to mainstream poor, women and youth for their active participation in decisions making and benefit sharing.

Agricultural Technology Management Agencies (ATMA) created large number of Farmer Interest Groups (FIG) in Nellore, Sangrur, Ratnagiri, Chittor and Patna and they were facilitated to collaborate with private extension players resulting in direct marketing of many farm produce (Srinath and Ponnusamy,2011). A producer group was formed in 2011 to produce and sell maize through PPP mode in Khurda district of Odishafor tribal men and women (Ponnusamy and Kishore, 2012). PPP in social mobilization is a grouping factor which is eradicating invisible social discriminations and social immorality prevailed in our Indian society. Increased Productivity: The transfer of Bt cotton technology to India was initiated by ICAR and Department of Biotechnology, Government of India by Monsanto. Subsequently, Mahyco went into partnership with Monsanto, which finally resulted in the introduction of $\mathrm{Bt}$ cotton in India (APCoAB, 2007).

India experienced an unintended increase in Bt cotton acreage from 29000 hectare in 2002 to 9.4 million hectare in 2010 (James, 2010). Bt cotton technology has brought in more equality in farm-income distribution (Morse et al., 2007). The productivity of cotton has increased to $526 \mathrm{~kg} / \mathrm{ha}$ in 2009-10 from 301 
$\mathrm{kg} / \mathrm{ha}$ in 2002-03 and reduction in real cost of production ranged from 16 to 46 per cent (Ramasundaram et al., 2011).

\section{Economic empowerment}

PPP for service delivery have revealed significant opportunities for women entrepreneurs and groups in delivering local services and creating conditions for empowerment at the grass root level. The PPP between Cadbury India, Kerala Agricultural University and DBT during past 23 years trained 250 women and established 28 cocoa chocolate units in different parts of Kerala. Thirumadhuram Pineapple project through PPP involving Kudumbhasree Project Mission, Department of Agriculture, women SHGs and Nadukkora Agro processing centre could produce 25000 tonnes of pineapple in 500 ha and directly employed 12500 women (Rajendran et al., 2010). PPP in vegetable marketing in Coimbatore district of Tamil Nadu enhanced the income level of farmwomen by 20 per cent (Thangamani et al., 2012).

\section{Model 1}

Fixed Pay off Run Business

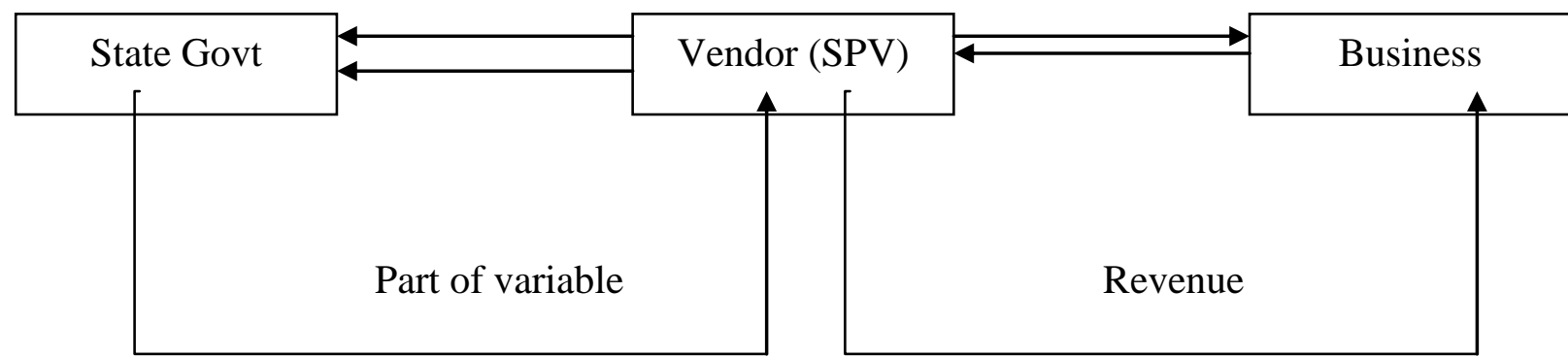

Administrative control

Capital investment

Model 2

Fixed Pay off Run Business

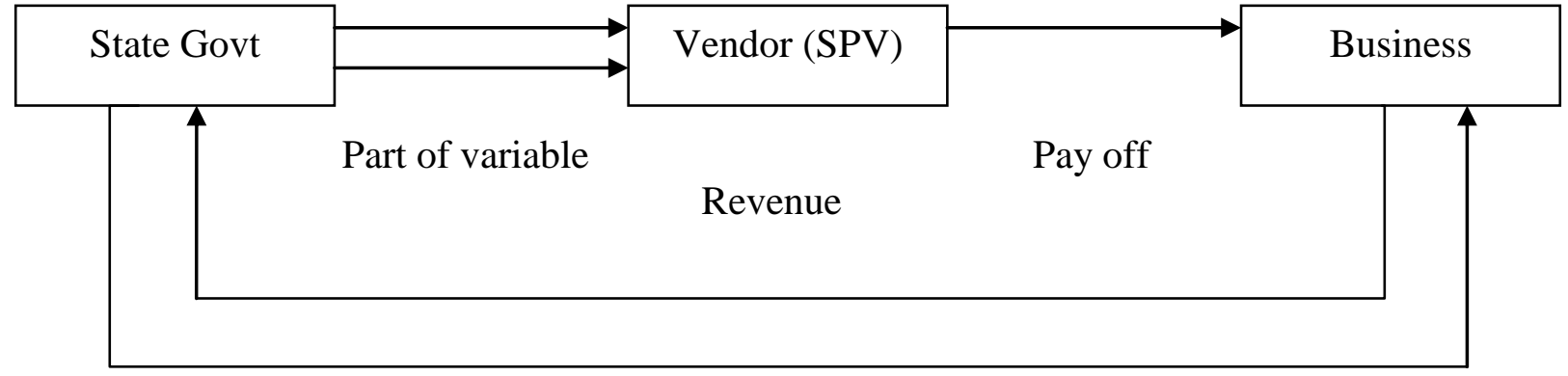

Capital investment 


\section{Model 3}

Fixed Pay off Run Business

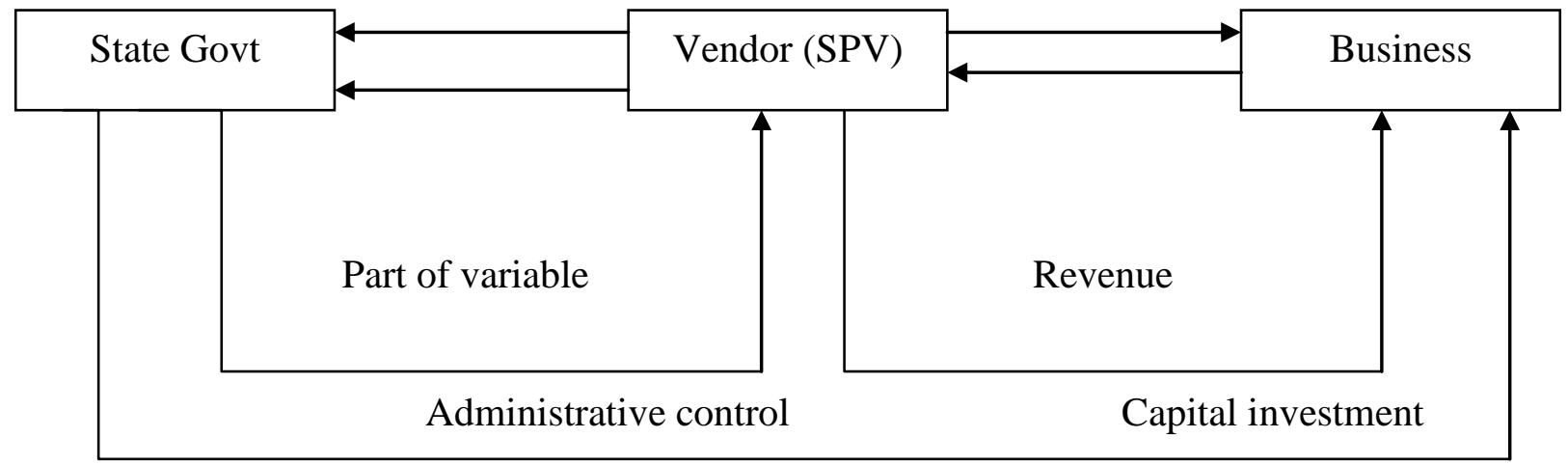

Reduction of risks and uncertainties: PPP has the potential to reduce risks and uncertainties related to crop failure, pest and diseases, natural calamities and natural resource management. Food safety-related barriers in the export context were addressed through PPP approach for green beans in Kenya and grapes in India. Insurance against drought was made truly affordable in 2009 through PPP between Syngenta East Africa Limited, MEA (a fertilizer company), KilimoSalama's agribusiness partners and KilimoSalama's telecommunications partner Safaricom using weather station data resulting in faster payments through phone and reduction in cost of insurance (Narrod et al., 2007). John Deere, a leading farm implements manufacturing company helped to promote mechanized farming in tribal region of Gujarat by establishing 8 Agricultural Implements Resource Centers each covering 600 acres of cultivated land through PPP (Reddy and Rao, 2011).

\section{Limitations of PPP models in agriculture}

Most of the farmers in India are belonged to small and marginal category having lack of capacity to raise their own capital to finance their agriculture based venture and the policy did not have interest in PPP for farmer welfare. The problem is further compounded where the proposed facility depends on a single commodity grown by small scale farmers carrying high levels of production risk (NAO, 2008). PPP in agriculture suffers due to problems linked with supply of raw materials, mode of procurement and rate fixing and thereby affecting cooperation and coordination between the partners. The performance of private extension is said to vary widely and tends to focus its services on areas with sufficient resources and is limited to a few crops and areas where profits can be assured (Sulaiman and Van Den Ban, 2003).

In recent decades, Public-Private Partnerships (PPP) has gained increasing attention and popularity because they are believed to be effective and efficient strategies to deal with such increasingly complex and wicked governance issues. PPP are now a widespread instrument of governance in society. However, partnerships between public and private actors are no easy feat. Public and private actors operate in different systems, with different values, practices and institutional logics; moreover, the sociopolitical environments in which PPP are planned and implemented are very complex and uncertain. Each PPP model is unique and has a well-defined understanding among the partners regarding the working relations and outputs. In each model, there should be clarity 
on sharing of fund investment, research and development components and business operations. A consortium involving unequal partners may not yield a viable partnership. Further, the models should take into their ambit of the whole chain from innovative product development to marketing.

\section{References}

Ahmed RA, Prusty K, Jena J, (2012). Prevailing human carnivore conflict in Kanha-Achanakmarcorridor), Central India. World JournalZool, 7(2):15864

APCoAB. 2007. Brainstorming Session on Models of Public-Private Partnership in Agricultural Biotechnology Highlights and Recommendations. $p$ 24+viii. Asia-Pacific Consortium on Agricultural Biotechnology, New Delhi and Trust for Advancement of Agricultural Sciences, New Delhi

Anonymus. 2014. Public-Private Partnerships for Agricultural Innovation: $6^{\text {th }}$ meeting of the Food Chain Analysis Network, Paris, 13-14 October 2014 Paris. Retrieved on 3/08/17 https://www.oecd.org/site/agrfen/Age nda_PPP\%20meeting_1314\%200ctob er\%202014\%20FINAL.pdf

Grout, P.A. and Stevens, M. 2003. The assessment: financing and managing public services. Oxford Review of economic policy, 19(2): 215-234.

Hisrich R D and Peters M P. 2002. Entrepreneurship. Tata McGraw Hill Publishing Company Ltd. New Delhi: 1-663.

Hodge, G. A and Greve, C. 2007. PublicPrivate Partnerships: An International Performance Review, Public Administration Review. 67(3): 545558

James, C. 2010. Global status of commercialized Biotech/GM crops: 2010. ISAAA briefs, (42).
Khush, G.S. 2005. Public-Private Partnership in Agricultural Biotechnology. Second Foundation Day Lecture Trust for Advancement of Agricultural Sciences, New Delhi: 1-20.

Morse S, Bennett R. and Ismael Y. 2005. Genetically modified insect resistance in cotton: Some earn-level economic impacts in India. Crop Protection 24: 433-40

Nanda, S.S.2015. Infrastructure Development in India: The Role of Public-Private Partnership. International Journal of Core Engineering and Management, 2(6):60-70.

NAO. 2008. "Public-private Partnerships and Agroprocessing Facilities", Marketoriented agricultural infrastructure: appraisal of public-private partnerships, agricultural management, marketing and finance. Occasional paper 23, NAO, Rome: 79 103.

Narrod, C., Roy, D., Okello, J., Avendaño, B., Rich, K. and Thorat, A. 2007. The role of public-private partnerships and collective action in ensuring smallholder participation in high value fruit and vegetable supply chains. International food policy research institute (IFPRI): for CGIAR system wide program on collective action and property rights (CAPRi).

Paul, A. G. and Margaret, S.2003. Financing and Managing Public Services: An Assessment. Programme on Public Private Partnership in Social Sector Chapter 6. Bella Vista Publication, Hyderabad

Ponnusamy, K. and Kishore, K. 2012. Empowerment of farm women through Public Private Partnership. Kheti, 64(12): 28-30.

Ramasundaram, P., Kurup, S. A., and Chand, R. 2011. Maneuvering Technology for 
Surplus Extraction: The Case of $\mathrm{Bt}$ Cotton in India. Policy Brief, 37.

Rajendran P, Prasad R. M. and BinooP. B. 2010. Proceedings of National Workshop on Public Private Partnership for Gender Mainstreaming in Agri-entrepreneurship Development. Nov2011, Kerala Agriculture University, Vellanikara, Kerala: $1-113$

Reddy, G.P. and Rao, K.H. 2011. Public Private Partnership in AgricultureChallenges and Opportunities, Summary proceedings and recommendations of NAARM. National Workshop held on September $19 \&$ 20, 2011. National academy of Agricultural research Management, Hyderabad 500 407, Andhra Pradesh, India.

Scharle, P. 2002. Public-private partnership (PPP) as a social game. Innovation: The European Journal of Social Science Research, 15(3): 227-252.

Spielman, D.J. and von Grebmer, K. 2004. Public-private partnerships in agricultural research: an analysis of challenges facing industry and the Consultative Group on International Agricultural Research (Vol. 113). International Food Policy Research Institute.

Srinath, K. and Ponnusamy, K. 2011. Gender Mainstreaming through Public Private Partnership in Agriculture. Proceedings of the National Workshop on Engendering Agriculture Production and Marketing through PPP, Feb 2011, Avinashilingam University for Women Coimbatore: 817.

Sulaiman,R. and A. W. Van Den Ban. 2003. Funding and Delivering Agricultural Extension Indian Journal of International Agricultural and Extension Education. 10(1): 21-30.

Thangamani, K., Leelavathy, K. C. and Meenakshi, S.2012. Mainstreaming of farmwomen: An experience of PPP approach in vegetable marketing. In Global Conference on Women in Agriculture: 13-15.

\section{How to cite this article:}

Chandan Kumar Rai, Arti, Sanjeev Kumar, Abul K. Azad and Mukesh Kumar 2017. Public Private Partnership in Agriculture: A Stern Review. Int.J.Curr.Microbiol.App.Sci. 6(9): 35103517. doi: https://doi.org/10.20546/ijcmas.2017.609.431 